DOI: 10.46340/eppd.2021.8.2.23

Anatolii Buriachenko

ORCID ID: https://orcid.org/0000-0001-7167-3294

Khmelnytsky University of Management and Law, Ukraine

\title{
ON THE ISSUE OF LEGAL REGULATION OF PARENTS' RESPONSIBILITY FOR INADMISSIBLE REALIZATION OF ALIMENTIAL OBLIGATIONS ACCORDING TO THE LEGISLATION OF UKRAINE AND OTHER STATES
}

\author{
Анатолій Буряченко \\ Хмельницький університет управління та права, Україна \\ ДО ПИТАННЯ ПРО ПРАВОВЕ РЕГУЛЮВАННЯ \\ ВІДПОВІДАЛЬНОСТІ БАТЬКІВ ЗА НЕНАЛЕЖНЕ \\ ВИКОНАННЯ АЛІМЕНТНИХ ЗОБОВ'ЯЗАНЬ \\ ЗА ЗАКОНОДАВСТВОМ УКРАЇНИ \\ ТА ІНШИХ ДЕРЖАВ
}

The scientific research of legal regulation of responsibility of parents for improper performance of alimony obligations under the legislation of Ukraine and other states is carried out in this scientific article. In particular, it is determined that the legislation of Ukraine provides for the possibility of collecting penalties (for alimony), interest (for additional costs for the child), fines applied by the state executor, temporary restrictions (also in terms of restricting the use of a number of special rights), as well as the right to hold positions in public authorities, the right to housing subsidies, the right to dispose of certain property, as well as the liability specified in the alimony agreement. All these types of liability exist in addition to administrative and criminal liability for breach of alimony.

The practice of application of Article 196 of the Family Code of Ukraine (which determines the recovery of penalties in the case of alimony arrears) by the Supreme Court of Ukraine is quite ambiguous. Thus, earlier when calculating the amount of the penalty, the court had to find out what are the unpaid amounts for each of these periods, set a deadline by which each of the obligations was to be fulfilled, and calculate the amount of interest for each month separately, summing up the accrued amount. Than the court summarizes penalty for each of the overdue payments and determines its total amount. Subsequently, from 2016, when calculating the total amount of penalty for late payment of alimony, the amount of unpaid alimony and the number of days in arrears began to be taken into account, and the amount of penalty is limited only by the amount of unpaid alimony for the month in which alimony was not collected. From 2018, the accrual of fines is not limited to the month in which the penalty was not collected.

Foreign experience in the legal regulation of liability for improper performance of alimony obligations by parents also provides for the arrest of the debtor for a certain period or before the original court decision, confiscation and sale of the debtor's property in favor of the child, deprivation of a license to implement assessment and mediation activities, placement of photos of non-payers on the Internet, deprivation of a driver's license, refusal to register a car or to issue inspection coupons, restriction of the debtor's use of payment cards.

Keywords: child support; alimony; additional costs for the child; penalty; temporary restrictions.

Постановка проблеми та ії зв'язок із важливими науковими та практичними проблемами.

Відповідно до ст. 180 Сімейного кодексу України (надалі за текстом - СК України) батьки зобов'язані утримувати дитину до досягнення нею повноліття, тобто мають щодо власних дітей відповідні аліментні зобов'язання. Як правило таке зобов'язання передбачає утримання дитини 
у грошовій або натуральній формі обома батьками, однак той з батьків, який не проживає спільно 3 дитиною, зобов'язаний здійснювати виконання аліментних зобов'язань саме в грошовій формі (у формі аліментів). Невиконання такого обов'язку зумовлює можливість примусового стягнення аліментів, адміністративну або кримінальну відповідальність, а також застосування додаткових санкцій, спрямованих на змушення боржника виконати свій обов'язок щодо утримання дитини. Попри те, що чинний СК України містить норми про відповідальність протягом всього часу дії цього нормативно-правового акту, в останні роки відбувається їх переопрацювання, зважаючи на достатньо велику кількість проблем щодо виплати та примусового стягнення аліментів на дитину. Як свідчать дані Єдиного реєстру боржників, до якого включено всіх фізичних осіб, щодо яких відкрито виконавче провадження з категорією стягнення "стягнення аліментів" та існує заборгованість більше ніж 3 місяці, станом на 20.12.2020 року знаходиться 175311 записів про боржників ${ }^{1}$, тобто 117,5 тисячі дітей і зараз не можуть отримати належного їм утримання. Вище викладене зумовлює необхідність удосконалення правового інституту відповідальності за неналежне виконання або невиконання батьками своїх аліментних зобов'язань, в тому числі в аспекті вивчення зарубіжного досвіду правового регулювання цього сімейно-правового

Аналіз останніх досліджень i публікацій, в яких започатковано розв'язання даної проблеми і на які опирається автор, виділення невирішених раніше частин загальної проблеми, котрим присвячується дана стаття.

На жаль, питання правового регулювання відповідальності батьків за неналежне виконання аліментних зобов'язань, хоч i було предметом окремих досліджень таких учених, як М. В. Антокольська, Л. П. Биряк, С.М. Ворожейкін, Н. М. Гресь, В.І. Данілін, М. В. Колеснікова, Л. В. Красицька, М. І. Кулеба, М.С. Малєін, В.П. Нікітін, О.Й. Пергамент, О. В. Розгон, Л. Ю. Сайко, Р. С. Чугунков, однак зазначені науковці не здійснили комплексного дослідження даного питання, в тому числі питання правового регулювання зазначеного питання за сімейним законодавством інших держав.

Формулювання цілей статті. Метою цієї наукової статті є наукове дослідження правового регулювання відповідальності батьків за неналежне виконання аліментних зобов'язань за законодавством України та інших держав.

Виклад основного матеріалу дослідження.

У науці сімейного права $є$ декілька підходів до питання щодо змісту поняття відповідальності батьків за неналежне виконання аліментних зобов'язань. Зокрема, на думку одних учених до заходів відповідальності відноситься навіть примусове стягнення аліментів (це думка таких вчених як Є. М. Ворожейкін та О. Й. Пергамент), з іншого боку на думку М. В. Антокольської. Н. М. Гресь, $\begin{array}{llll}\text { B. I. Даніліна, } & \text { М. С. Малєіна. } & \text { В. П. Нікітіної стягнення аліментів у судовому порядку }\end{array}$ не $є$ відповідальністю, а є заходом захисту; відповідальністю ж $є$ інші заходи, в тому числі неустойка, окремі обмеження для боржника, спрямовані на відновлення належного виконання одним з батьків своїх аліментних зобов'язань щодо дитини ${ }^{2}$.

Відповідно до ст. 196 СК України у разі виникнення заборгованості з вини особи, яка зобов'язана сплачувати аліменти за рішенням суду або за домовленістю між батьками, одержувач аліментів має право на стягнення неустойки (пені) у розмірі одного відсотка суми несплачених аліментів за кожен день прострочення (хоча цей розмір може бути зменшений судом з урахуванням матеріального та сімейного стану платника аліментів, а також не застосованим, якщо платник аліментів $є$ неповнолітнім), але не більше 100 відсотків заборгованості. Неустойка не сплачується, якщо платник аліментів $\epsilon$ неповнолітнім. У разі прострочення оплати додаткових витрат на дитину 3 вини платника такий платник зобов'язаний на вимогу одержувача додаткових витрат сплатити суму заборгованості за додатковими витратами з урахуванням встановленого індексу інфляції за весь час прострочення, а також три проценти річних із простроченої суми ${ }^{3}$.

\footnotetext{
${ }^{1}$ Міністерство юстиції України (2020). Сдиний реєстр боржників (заборгованість по аліментам) $<$ https://erb.minjust.gov.ua/\#/search-debtors> (2020, грудень, 20)

${ }^{2}$ Багач, Е. М., Білоусов, Ю. В. (2010). Сімейний кодекс Украйни: науково-практичний коментар. Київ: Ліга, 101; Гресь, Н. М. (2017). Окремі аспекти відповідальності за невиконання батьками аліментних зобов'язань.

Приватне та публічне право, 1, 9-10; Гресь, Н. М. (2015). Проблемні питання відповідальності за несплату та прострочення сплати батьками аліментів на утримання неповнолітніх дітей. Порівняльно-аналітичне право, 6, 46 <http://pap-journal.in.ua/wp-content/uploads/2020/07/6_2015.pdf> (2021, березень, 20).

${ }^{3}$ Сімейний кодекс Украӥни, 2002 (Верховна Рада України). Офіиійний сайт Верховної Ради Украӥни <https://zakon.rada.gov.ua/laws/show/2447-14> (2021, березень, 20).
} 
У той же час, як зазначає Л. В. Красицька, дана норма є застосовною тільки у випадку, коли аліменти стягуються за рішенням суду. Якщо сплата аліментів здійснюється на підставі аліментного договору, то не виникає підстав для застосування ст. 196 СК України. Пункт 22 Постанови Пленуму Верховного Суду України «Про застосування судами окремих норм Сімейного кодексу України при розгляді справ щодо батьківства, материнства та стягнення аліментів» від 15 травня 2006 року №3 передбачає: якщо аліменти сплачуються не за рішенням суду, а згідно з укладеним між батьками договором, передбачена ст. 196 СК санкція застосовується за наявності прямої вказівки про це в договорі ${ }^{1}$. Тієї ж думки дотримується Н. М. Гресь ${ }^{2}$. Вона також наполягає на тому, що, як свідчить аналіз судової практики про стягнення неустойки та прострочення сплати аліментів, суди по-різному підходять до вказаного питання і досить часто застосовують своє право зменшити розмір неустойки 3 урахуванням матеріальною та сімейною стану платника ${ }^{3}$. В той же час, слід зазначити, що чинна редакція ст. 196 СК України передбачає можливість стягнення неустойки також і щодо невиконаних аліментних зобов'язань, визначених аліментним договором ${ }^{4}$.

Слід зазначити, що практика застосування ст.196 СК України Верховним Судом України є досить неоднозначною. Так, Судова палата у цивільних справах Верховного Суду України, розглянувши справу №6-81цс13, у постанові від 11 вересня 2013 року зробила висновок, що при розгляді спорів про стягнення на підставі ч.1 ст.196 СК України пені суд повинен з'ясувати, якими $\epsilon$ несплачені суми за кожен із цих періодів, установити строк, до якого кожне із зобов'язань мало бути виконане, та обчислити розмір пені за кожен місяць окремо (від дня порушення платником аліментів свого обов'язку до дня ухвалення судом рішення про стягнення пені), підсумувавши розміри нарахованої пені за кожен із прострочених платежів та визначивши ії загальну суму». У постанові Верховного Суду України від 16 березня 2016 року у справі №6-300цс16 сказано, що при обчисленні загальної суми пені за прострочення сплати аліментів ураховується сума несплачених аліментів та кількість днів прострочення, а сума нарахування пені обмежується лише сумою несплачених аліментів за той місяць, в якому не проводилося стягнення аліментів ${ }^{5}$. В подальшому, відповідно до правової позиції висловленої в постанові Великої Палати Верховного Суду від 25 квітня 2018 року по справі № 572/1762/15-ц, було визначено, що, пеня за прострочення сплати аліментів повинна нараховуватися на всю суму несплачених аліментів за кожен день прострочення iї сплати, а їі нарахування не обмежується тільки тим місяцем, у якому не проводилося стягнення 6 .

Також законодавство України передбачає адміністративну відповідальність за несплату аліментів на дитину, якщо сукупний розмір заборгованості перевищує суму відповідних платежів за 6 місяців із дня пред'явлення виконавчого документа до примусового виконання для здорових дітей та в разі заборгованості за 3 місяці для дітей, які мають проблеми зі здоров'ям, передбачені у ст. 183-1 КУПАП, а також передбачено кримінальну відповідальність за злісне ухилення від сплати встановлених рішенням суду коштів на утримання дітей (аліментів), а також злісне ухилення батьків від утримання неповнолітніх або непрацездатних дітей, що перебувають на їх утриманні (ст. 164 Кримінального кодексу України).

\footnotetext{
${ }^{1}$ Красицька, Л. В. (2015). Неустойка як гарантія захисту права дитини на утримання. Міжнародний юридичний вісник: збірник наукових праџь Наџіонального університету державної податкової служби України, 1 (2), 183. ${ }^{2}$ Гресь, Н. М. (2017). Окремі аспекти відповідальності за невиконання батьками аліментних зобов'язань. Приватне та публічне право, 1, 10; Гресь, Н. М. (2015). Проблемні питання відповідальності за несплату та прострочення сплати батьками аліментів на утримання неповнолітніх дітей. Порівняльно-аналітичне право, 6 , 84 <http://pap-journal.in.ua/wp-content/uploads/2020/07/6_2015.pdf> (2021, березень, 20).

${ }^{3}$ Гресь, Н. М. (2015). Проблемні питання відповідальності за несплату та прострочення сплати батьками аліментів на утримання неповнолітніх дітей. Порівняльно-аналітичне право, 6, 84 <http://pap-journal.in.ua/ wp-content/uploads/2020/07/6_2015.pdf > (2021, березень, 20).

${ }^{4}$ Сімейний кодекс Украӥни, 2002 (Верховна Рада України). Офіиійний сайт Верховної Ради Украӥни <https://zakon.rada.gov.ua/laws/show/2447-14> (2021, березень, 20).

${ }^{5}$ Кулеба, М., Простибоженко, О., Савицька, С. (2017). Неоднозначна неустойка. Висновки ВСУ щодо обрахування пені від суми несплачених аліментів спричинили невизначеність із застосуванням ст.196 СК. Закон $і$ бізнес, 12 (310) <https://zib.com.ua/ua/print/128140-visnovki_vsu_schodo_obrahuvannya_peni_vid_sumi_nesplachenih_.html> (2021, березень, 20).

${ }^{6}$ WikiLegalAid: довідково-інформаційна платформа правових консультацій (2021). Стягнення неустойки (пені) за несвоєчасну сплату аліментів <https://wiki.legalaid.gov.ua/index.php/Стягнення_неустойки_(пені)_ за_несвоєчасну_сплату_аліментів> (2021, березень, 20).
} 
Також в СК України у ч. 1 ст. 196 містить положення про те, що у разі застосування до особи, яка зобов'язана сплачувати аліменти за рішенням суду, заходів, передбачених частиною чотирнадцятою статті 71 Закону України «Про виконавче провадження», максимальний розмір пені повинен дорівнювати різниці між сумою заборгованості та розміром застосованих заходів примусового виконання, передбачених частиною чотирнадцятою статті 71 Закону України «Про виконавче провадження» ${ }^{1}$. Такими заходами $\epsilon$ штраф у розмірі $20 \%$ суми заборгованості зі сплати аліментів, за наявності заборгованості зі сплати аліментів, сукупний розмір якої перевищує суму відповідних платежів за один рік (у разі перевищення суми за два роки - 30\%, три роки - 50\%). Зазначений штраф стягується державним виконавцем з боржника і перераховуються стягувачу ${ }^{2}$.

Також щодо осіб, які більше 6 місяців не сплачують аліменти, виконавчою службою може бути винесено постанову про застосування до боржника одного з тимчасових обмежень: про встановлення тимчасового обмеження боржника у праві виїзду за межі України; про встановлення тимчасового обмеження боржника у праві керування транспортними засобами; про встановлення тимчасового обмеження боржника у праві користування вогнепальною мисливською, пневматичною та охолощеною зброєю, пристроями вітчизняного виробництва для відстрілу патронів, споряджених гумовими чи аналогічними за своїми властивостями метальними снарядами несмертельної дії; про встановлення тимчасового обмеження боржника у праві полювання. Ці обмеження застосовуються в повному обсязі до моменту погашення заборгованості, за окремими винятками, спрямованих на захист інтересів боржника, коли застосування такої заборони є недоцільним, зокрема 3 підстав, якщо наприклад водіння транспортним засобом є основним джерелом доходу боржника або відбувається у зв'язку з інвалідністю або перебуванням на утриманні особи з інвалідністю 1 або 2 групи, тощо ${ }^{3}$.

Вище викладені обмеження не $є$ вичерпними і законодавство України також передбачає й інші обмеження для неплатників аліментів. Зокрема таким особам при наявності заборгованості по аліментам понад три місяці не призначається житлова субсидія (при заборгованості понад три місяці) $)^{4}$ відмовляється у державній реєстрацію права власності щодо нерухомого майна, у вчиненні нотаріальної дії щодо відчуження належного майна, у перереєстрації, зняття з обліку транспортного засобу з метою його відчуження, відмовляється у державній реєстрації змін до відомостей Єдиного державного реєстру, пов'язаних із зміною засновників (учасників) юридичної особи у зв'язку із зміною частки засновника (учасника) у статутному (складеному) капіталі (пайовому фонді) юридичної особи (крім випадку збільшення розміру такої частки), встановлюються обмеження у праві здійснення державної служби. У разі заборгованості понад шість (в окремих випадках дванадцяти) місяців з дня пред'явлення виконавчого документа до примусового виконання, особа обмежується у реалізації права на зайняття посад в органах державної влади, а у разі, якщо особа вже перебуває на посаді в органі державної влади, ії повноваження можуть бути достроково припинені (останнє стосується навіть повноважень депутата місцевої ради) 5 . Також сторони у аліментному договорі вільні у виборі інших санкцій за невиконання аліментного зобов'язання'

Якщо говорити про зарубіжний досвід правового регулювання відповідальності за неналежне виконання батьками своїх аліментних зобов'язань, то слід зазначити, що боротьба з неплатниками аліментів щодо їх сплати в низці американських, європейських країн передбачає значно суворіші механізми відповідальності недобросовісних батьків, ніж в Україні. Зокрема, у Великобританії передбачається кримінальна відповідальність за злісне невиконання боржником судового рішення про виплату аліментів, зокрема за виплату аліментів не в повному обсязі чи відмову від виплати передбачається наказ про арешт боржника на певний термін або до виконання первісного судового

\footnotetext{
${ }^{1}$ Сімейний кодекс Украӥни, 2002 (Верховна Рада України). Офіиійний сайт Верховної Ради України $<$ https://zakon.rada.gov.ua/laws/show/2447-14> (2021, березень, 20).

2 Закон про виконавче провадження, 2016 (Верховна Рада України). Офіиійний сайт Верховної Ради України. <https://zakon.rada.gov.ua/laws/show/1404-19> (2021, березень, 20).

3 Там само.

${ }^{4}$ Відповідальність за несплату аліментів. WikiLegalAid: довідково-інформаційна платформа правових консультацій. https://wiki.legalaid.gov.ua/index.php/Відповідальність_за_несплату_аліментів (2021, березень, 20).

${ }^{5}$ WikiLegalAid: довідково-інформаційна платформа правових консультацій (2021). Вiдповідальність за прострочення сплати аліментів <https://wiki.legalaid.gov.ua/index.php/Відповідальність_за_прострочення сплати_аліментів $>(2021$, березень, 20).

${ }^{6}$ Розгон, О. В. (2018). Договори у сімейному праві Украӥни. Київ: Ін Юре, 194.
} 
рішення, а за злісне невиконання судових приписів, наявність заборгованості 3 аліментних зобов'язань передбачається відповідальність у вигляді позбавлення волі строком до 15 місяців ${ }^{1}$ Кримінальна відповідальність за несплату аліментів у вигляді позбавлення волі строком до двох років передбачається за законодавством США⿱2 , а німецьке законодавство передбачає трирічне ув'язнення, хоча можливою $є$ й конфіскація та продаж майна боржника на користь дитини ${ }^{3}$. Позбавлення волі загрожує злісним неплатникам аліментів також у Франції, Італії, Азербайджані та ін. ${ }^{4}$ У США та Канаді злісних неплатників аліментів можуть позбавити водійських посвідчень, ліцензії на ловлю риби чи полювання, заняття оціночною, медиаторською діяльністю або ліцензії нотаріуса; державні органи можуть оприлюднювати фотографії неплатників у мережі інтернет ${ }^{5}$ У Латвії діє закон, відповідно до якого ті батьки, за кого мінімальні аліменти платить держава, позбавляються водійського посвідчення, передбачається відмова в реєстрації автомобіля або у видачі талонів техогляду ${ }^{6}$. В Ізраїлі можливе обмеження боржника у використанні платіжних карток ${ }^{7}$

Висновки, зроблені в результаті дослідження і перспективи подальших розвідок у даному напрямку.

На основі проведеного дослідження приходимо до наступних висновків.

У науці сімейного права є декілька підходів до питання щодо змісту поняття відповідальності батьків за неналежне виконання аліментних зобов'язань: до такої відповідальності часто відносять примусове стягнення заборгованості по аліментах, однак більш поширеним є підхід відповідно до якого відповідальністю є інші заходи, в тому числі неустойка, окремі обмеження для боржника, спрямовані на відновлення належного виконання одним з батьків своїх аліментних зобов'язань щодо дитини.

Законодавство України передбачає, крім адміністративної та кримінальної відповідальності за порушення аліментних зобов'язань, також можливість стягнення неустойки (щодо аліментів), процентів (щодо додаткових витрат на дитину), штраф, який застосовується державним виконавцем, тимчасові обмеження, в тому числі в аспекті обмеження користування рядом спеціальних прав, а також прав на зайняття посад в органах державної влади, права на житлову субсидію, прав на розпорядження окремим майном, а також відповідальність, визначену у аліментному договорі.

Практика застосування ст.196 СК України (що визначає стягнення неустойки уразі заборгованості по аліментах) Верховним Судом України є досить неоднозначною. Так, раніше при розрахунку суми пені суд повинен був з'ясувати, якими є несплачені суми за кожен із цих періодів, установити строк, до якого кожне із зобов'язань мало бути виконане, та обчислити розмір пені за кожен місяць окремо, підсумувавши розміри нарахованої пені за кожен із прострочених платежів та визначивши іï загальну суму». В подальшому, з 2016 року при обчисленні загальної суми пені за прострочення сплати аліментів почали враховуватися сума несплачених аліментів та кількість днів прострочення, а сума нарахування пені обмежується лише сумою несплачених аліментів за той

\footnotetext{
${ }^{1}$ Obozrevatel (2018). Як у світі карають злісних неплатників аліментів

<https://www.obozrevatel.com/ukr/law/yak-v-sviti-karayut-zlisnih-neplatnikiv-alimentiv.html> (2019, травень, 15).

${ }^{2}$ Колеснікова, М. В., Биряк, Л. П. (2019). Деякі аспекти сплати аліментів в Україні та за кордоном. Юридичний науковий електронний журнал, 3, 61 <http://www.lsej.org.ua/3_2019/16.pdf> (2021, березень, 20).

${ }^{3}$ Obozrevatel (2018). Як у світі карають злісних неплатників аліментів

<https://www.obozrevatel.com/ukr/law/yak-v-sviti-karayut-zlisnih-neplatnikiv-alimentiv.html> (2018, травень, 15).

4 Там само.

${ }^{5}$ Сайко, Л. Ю. (2012). Окремі аспекти процедури примусового виконання рішень судів про стягнення аліментів. Electronic Sumy State University Institutional Repository <https://essuir.sumdu.edu.ua/bitstream-download/123456789/ 29044/1/alimony.pdf> (2021, березень, 20); Obozrevatel (2018). Як у світі карають злісних неплатників аліментів <https://www.obozrevatel.com/ukr/law/yak-v-sviti-karayut-zlisnih-neplatnikiv-alimentiv.html> (2018, травень, 15).

${ }^{6}$ Сайко, Л. Ю. (2012). Окремі аспекти процедури примусового виконання рішень судів про стягнення аліментів. Electronic Sumy State University Institutional Repository <https://essuir.sumdu.edu.ua/bitstream-download/ 123456789/29044/1/alimony.pdf> (2021, березень, 20); LB.ua (2016). У Латвї неплатників аліментів будуть позбавляти водійських прав <https://ukr.lb.ua/world/2016/12/01/352342_latvii_neplatnikiv_alimentiv.htm> (2021, березень, 20).

${ }^{7}$ Сайко, Л. Ю. (2012). Окремі аспекти процедури примусового виконання рішень судів про стягнення аліментів. Electronic Sumy State University Institutional Repository <https://essuir.sumdu.edu.ua/bitstream-download/ 123456789/29044/1/alimony.pdf> (2021, березень, 20).
} 
місяць, в якому не проводилося стягнення аліментів. 32018 року нарахування пені не обмежується тільки тим місяцем, у якому не проводилося стягнення.

Зарубіжний досвід правового регулювання відповідальності за неналежне виконання батьками своїх аліментних зобов'язань передбачає також арешт боржника на певний термін або до виконання первісного судового рішення, конфіскація та продаж майна боржника на користь дитини, позбавлення ліцензії на заняття оціночною, медиаторською діяльністю або ліцензії нотаріуса, оприлюднення фотографій неплатників у мережі інтернет, позбавлення водійського посвідчення, відмова в реєстрації автомобіля або у видачі талонів техогляду, обмеження боржника у використанні платіжних карток.

\section{References:}

1. Bahach, E. M., Bilousov, Yu. V. (2010). Simeinyi kodeks Ukrainy: naukovo-praktychnyi komentar [Family Code of Ukraine: scientific and practical commentary]. Kyiv: Liha. [in Ukrainian].

2. WikiLegalAid: dovidkovo-informatsiina platforma pravovykh konsultatsii (2021) [WikiLegalAid: a reference and information platform for legal advice (2021)]. Vidpovidalnist za nesplatu alimentiv [Liability for non-payment of alimony] <https://wiki.legalaid.gov.ua/index.php/Відповідальність_за_несплату_аліментів> (2021, March, 20). [in Ukrainian].

3. WikiLegalAid: dovidkovo-informatsiina platforma pravovykh konsultatsii (2021) [WikiLegalAid: a reference and information platform for legal advice (2021)]. Vidpovidalnist za prostrochennia splaty alimentiv [Liability for late payment of alimony]. <https://wiki.legalaid.gov.ua/index.php/Відповідальність_за_прострочення_ сплати_аліментів> (2021, March, 20). [in Ukrainian].

4. Hres, N. M. (2017). Okremi aspekty vidpovidalnosti za nevykonannia batkamy alimentnykh zoboviazan [Some aspects of liability for non-compliance with parental maintenance obligations]. Pryvatne ta publichne pravo [Private and public law], 1, 9-13. [in Ukrainian].

5. Hres, N. M. (2015). Problemni pytannia vidpovidalnosti za nesplatu ta prostrochennia splaty batkamy alimentiv na utrymannia nepovnolitnikh ditei [Problematic issues of liability for non-payment and late payment of alimony by parents for the maintenance of minor children]. Porivnialno-analitychne pravo [Comparative and analytical law], 6, 83-86<http://pap-journal.in.ua/wp-content/uploads/2020/07/6_2015.pdf > (2021, March, 20). [in Ukrainian].

6. Ministerstvo yustytsii Ukrainy (2020) [Ministry of Justice of Ukraine (2020)]. Yedynyi reiestr borzhnykiv (zaborhovanist po alimentam) [Unified register of debtors (alimony arrears)] <https://erb.minjust.gov.ua/\#/search-debtors> (2020, December, 20). [in Ukrainian].

7. Kolesnikova, M. V., Byriak, L. P. (2019). Deiaki aspekty splaty alimentiv v Ukraini ta za kordonom [Some aspects of alimony payment in Ukraine and abroad]. Yurydychnyi naukovyi elektronnyi zhurnal [Legal scientific electronic journal], 3, 60-62 <http://www.lsej.org.ua/3_2019/16.pdf>. (2021, March, 20). [in Ukrainian].

8. Krasytska, L. V. (2015). Neustoika yak harantiia zakhystu prava dytyny na utrymannia [Penalty as a guarantee of protection of the child's right to maintenance]. Mizhnarodnyi yurydychnyi visnyk: zbirnyk naukovykh prats Natsionalnoho universytetu derzhavnoi podatkovoi sluzhby Ukrainy [International Legal Bulletin: a collection of scientific papers of the National University of the State Tax Service of Ukraine], 1 (2), 182-189. [in Ukrainian].

9. Kuleba, M., Prostybozhenko, O., Savytska, S. (2017). Neodnoznachna neustoika. Vysnovky VSU shchodo obrakhuvannia peni vid sumy nesplachenykh alimentiv sprychynyly nevyznachenist iz zastosuvanniam st.196 SK [Ambiguous penalty. The conclusions of the Supreme Court of Ukraine on the calculation of the penalty for the amount of unpaid alimony caused uncertainty with the application of Article 196 of the Family Code]. Zakon i biznes [Law and business], 12 (310) <https://zib.com.ua/ua/print/128140-visnovki_vsu_schodo_obrahuvannya_peni_ vid_sumi_nesplachenih_.html> (2021, March, 20). [in Ukrainian].

10.Zakon pro vykonavche provadzhennya, 2016 (Verkhovna Rada Ukrajiny). [Law on Enforcement 2016 (Verkhovna Rada of Ukraine)]. Ofitsiinyi sait Verkhovnoi Rady Ukrainy [ The official site of the Verkhovna Rada of Ukraine] <https://zakon.rada.gov.ua/laws/show/1404-19> (2021, March, 20). [in Ukrainian].

11. Rozghon, O. V. (2018). Dohovory u simeinomu pravi Ukrainy [Agreements in family law of Ukraine]. Kyiv: In Yure.

12. Saiko, L. Yu. (2012). Okremi aspekty protsedury prymusovoho vykonannia rishen sudiv pro stiahnennia alimentiv [Some aspects of the procedure of enforcement of court decisions on the recovery of alimony]. Electronic Sumy State University Institutional Repository <https://essuir.sumdu.edu.ua/bitstream-download/123456789/29044/ 1/alimony.pdf;jsessionid=3DC7F55C4A875A0DEE9A0AE9DDF12B64> (2021, March, 20). [in Ukrainian].

13. Simeinyi kodeks Ukrainy, 2002 (Verkhovna Rada Ukrainy) [Family Code of Ukraine, 2002 (Verkhovna Rada of Ukraine)]. Ofitsiinyi sait Verkhovnoi Rady Ukrainy [The official site of the Verkhovna Rada of Ukraine]. <https://zakon.rada.gov.ua/laws/show/2447-14> (2021, March, 20). [in Ukrainian].

14. WikiLegalAid: dovidkovo-informatsiina platforma pravovykh konsultatsii (2021) [WikiLegalAid: a reference and information platform for legal advice (2021)]. Stiahnennia neustoiky (peni) za nesvoiechasnu splatu alimentiv [Collection of penalties (penalties) for late payment of alimony] 
<https://wiki.legalaid.gov.ua/index.php/Стягнення_неустойки_(пені)_за_несвоєчасну_сплату_аліментів> (2021, March, 20). [in Ukrainian].

15. LB.ua (2016). U Latvii neplatnykiv alimentiv budut pozbavliaty vodiiskykh prav [In Latvia, non-payers of alimony will be deprived of their driver's licenses] <https://ukr.lb.ua/world/2016/12/01/352342_latvii_neplatnikiv_alimentiv.htm> (2021, March, 20). [in Ukrainian].

16. Obozrevatel (2018) [Observer (2018)]. Yak u sviti karaiut zlisnykh neplatnykiv alimentiv [How the world punishes malicious non-payers of alimony] <https://www.obozrevatel.com/ukr/law/yak-v-sviti-karayut-zlisnih-neplatnikivalimentiv.html> (2019, March, 20). [in Ukrainian]. 